\title{
Effectiveness of innovative solutions in an energy company
}

\author{
$A$ Minnullina $^{1, *}, R$ Minnullin $^{1}, A$ Antropova ${ }^{1}$ and $I$ Kosyakova $^{2}$ \\ ${ }^{1}$ Industrial University of Tyumen, Volodarskogo str. 38, Tyumen, Russia \\ ${ }^{2}$ Samara State Technical University, Molodogvardeyskaya street, 244, Samara, Russia
}

\begin{abstract}
The paper proposes a methodology for assessing the level of innovative growth of an energy company, which is based on the calculation of the integral indicator. Within the framework of the proposed method, the integral indicator of innovative growth is calculated according to four groups of indicators reflecting the results of the company's activities. In this case, unit and group weight coefficient are taken into account. In order to reflect the practical application of the results obtained, calculations of the main indicators of innovative growth of a large diversified energy company operating in the Tyumen and Kurgan regions were carried out. The result of a comprehensive assessment and the calculation of the integral indicator serve as final indicators that focus on the main problems of innovative growth and help to correct the identified inconsistencies in time.
\end{abstract}

\section{Introduction}

Nowadays, the fundamental factors in the growth of any company are innovative factors, including new equipment, system technologies of a new type, a new organization of labor and production, a new motivational system. Companies need to embrace innovation and bring it to market regularly and faster than existing and potential competitors, and innovation must be a systematic and controlled process.

The strategy of innovative growth can act as a tool for monitoring the implementation and combination of various innovations, as well as increasing the innovative activity of companies. As a characteristic reflecting the growth of the company in the aspect of the development of its innovative activity, it is necessary to substantiate and disclose the content of the definition of the innovative growth of a company.

The innovative growth of a company is a long-term increase in the value of the company based on the sale of products and services produced using new technologies, as well as the application of new organizational, technical and socio-economic solutions of an industrial, financial, commercial or administrative nature. It is innovative growth that leads to the creation and sale of competitive products and the improvement of the economic state of production [1].

According to the draft Energy Strategy of Russia that should be implemented until 2035, the energy industry is subject to structural transformation, including through

\footnotetext{
*Corresponding author: minnullinaay@yandex.ru
} 
increased spending on innovation and R\&D. Investment costs should increase to improve the competitiveness of Russian energy equipment, modernize the energy industry and ensure technological independence.

Innovation is a fairly broad concept that can imply a completely different level and scale of the proposed changes. Energy innovations do not always require years of scientific research and multi-million dollar investments. Often very small and quickly implemented projects bring much more positive effect than long-term large-scale developments. In practice, many projects that are based on innovative technology that can actually improve performance in any part of the energy business face a number of serious problems when trying to commercialize. Sometimes these problems are associated not with the innovation itself, but with a number of other factors that impede its implementation. For example, such a factor may be the duration or complete absence of a project's payback, even if the innovation objectively improves the performance of some part of the power system.

Many scientists have created a certain theoretical foundation for researching the company's innovative activities. Thus, the works of P.N. Zavlin, N.D. Kondratyev, G. Mensh, A.G. Porshnev, B. Santo, B. Twiss, R.A. Fatkhutdinov, R. Foster, H. Freeman, J. Schumpeter and others were of great importance in the development of the theory and practice of innovative management [1-5]. The works of V. Berens, A.K. Vatolin, A.Yu. Egorov, B.S. Kasaev, D. Clark, T.V. Kolosova, R. Crossley, E.Yu. Kuznetsov, M.I. Lomakin, V. Miller, H. Neubauer, A.I. Panov, A.A. Safronov, G. Stigler, A.A. Trifilov, D.V. Khavin, and K. Arrow are devoted to the process of organizing and assessing the effectiveness of the company's innovative activities [2, 6-10].

Despite a significant number of works, methods for assessing and ensuring the innovative growth of enterprises, including in the energy industry, have not been sufficiently studied in the economic literature. This area has not received wide coverage in Russian scientific works and has a certain novelty.

The Skolkovo Foundation has considerable experience in assessing innovative projects. Hundreds of new projects regularly pass through its expert committee. According to representatives of the fund, the reasons for stopping the development of startups can be completely different. In addition to the technical component of projects and the parameters of the device itself, a system or a set of measures, a high-quality presentation of the project and the ability to prove the possibility of effective application of innovation in modern energy are important.

In order to develop and promote promising energy projects and improve innovation in the electric power industry, an open area was created, which was named the "Innovations in the Electricity Industry" club. The club includes the heads and experts of the Ministry of Energy of Russia, SO UPS JSC, the Energy Producers Council Association, the NP Market Council Association, the Skolkovo Fund, MOEK PJSC, Gazprom Energoholding LLC, UC RUSAL, EuroSibEnergo JSC, as well as other representatives of enterprises related to the energy industry. Within the club, 5 working groups were formed to solve various problems related to the development of innovations.

When introducing innovations in capital-intensive industries such as the power industry, the effectiveness of government support programs is of great importance. In order to achieve the goals set by the draft Energy Strategy of Russia, it is obvious that it is necessary to improve measures of state support for innovation. Special attention should be paid to positive changes in lending programs with government support, as well as the need to synchronize and consolidate the regulatory framework in the field of innovation.

It should be understood that government support does not mean and is not limited to funding. First of all, state support should be expressed in changing the regulatory framework in order to simplify the transition to the use of innovative products in the production and at least remove the restrictions on the development of the energy industry, 
which have become irrelevant in the current market model. An example of such restrictions is the current ban on combining competitive and natural monopoly activities (generation and networks).

In the current market conditions, the efficiency of the energy industry is inextricably linked to the development of innovative solutions. For a gradual increase in the share of import substitution, it is necessary to support and develop an innovative environment and existing promising projects both at the level of the state and infrastructure organizations, and on the part of market participants.

It is important to understand that the implementation and development of innovative solutions in the activities of large energy companies in Russia that have been operating on the market for a long enough period must be viewed in dynamics. For this, it is advisable to conduct a regular comprehensive assessment of the innovative growth of an energy company. [11.12]

\section{Methods}

Let's consider an integrated approach to assessing the company's innovative growth, based on the definition of an integral indicator.

According to the recommended methodology, it is proposed to calculate the integral indicator using the following formula (1):

$$
I G=\sum_{i=1}^{n} \frac{\mathrm{P}_{w i * \mathrm{P}_{i}}}{100}
$$

where $P_{w}$-weight coefficients for indicators; $P_{i}$ - design value of an indicator $\%$.

The main indicators of the innovative growth of an energy company are the assessment of economic, production, human and innovative factors presented in Table 1.

Table 1. Key indicators of innovative growth of an energy company.

\begin{tabular}{|l|c|l|}
\hline $\begin{array}{l}\text { Indicator name } \\
\begin{array}{l}\text { Increase in } \\
\text { intangible assets }\end{array}\end{array}$ & \multicolumn{1}{|c|}{ Formula for calculating } & \multicolumn{1}{c|}{ Specification } \\
\hline $\begin{array}{l}\text { Increase in net } \\
\text { (retained) profit }\end{array}$ & $\mathrm{In}_{\mathrm{IA}}=\frac{\mathrm{Ia}_{1}-\mathrm{Ia}_{0}}{\mathrm{Ia}_{0}} * 100 \%$ & $\begin{array}{l}\mathrm{Ia}_{0}, \mathrm{Ia}_{1}-\text { cost of intangible } \\
\text { assets of the company at the } \\
\text { beginning and end of the } \\
\text { year, rub. }\end{array}$ \\
\hline $\begin{array}{l}3 \text { Increase in sales } \\
\text { revenue }\end{array}$ & $\mathrm{In}_{\mathrm{NP}}=\frac{\mathrm{P}_{1}-\mathrm{P}_{0}}{\mathrm{P}_{0}} * 100 \%$ & $\begin{array}{l}\mathrm{P}_{0}, \mathrm{P}_{1}-\text { net (retained) profit } \\
\text { of th company at the } \\
\text { beginning and end of the } \\
\text { year, rubles }\end{array}$ \\
\hline $\begin{array}{l}4 \text { Increase in fixed } \\
\text { and current assets } \\
\text { of the company }\end{array}$ & $\mathrm{In}_{\mathrm{SR}}=\frac{\mathrm{R}_{1}-\mathrm{R}_{0}}{\mathrm{R}_{1}} * 100 \%$ & $\begin{array}{l}\mathrm{R}_{0}, \mathrm{R}_{1}-\text { sales revenue at the } \\
\text { beginning and end of the } \\
\text { year, rub. }\end{array}$ \\
\hline $\begin{array}{l}5 \text { Flexibility } \\
\text { indicator, the } \\
\text { ability of a } \\
\text { company to } \\
\text { reallocate resources } \\
\text { from one type of } \\
\text { activity to another } \\
\text { to release new } \\
\text { products and } \\
\text { services }\end{array}$ & $\mathrm{In}_{\mathrm{A}}=\frac{\mathrm{A}_{1}-\mathrm{A}_{0}}{\mathrm{~A}_{0}} * 100 \%$ & $\begin{array}{l}\mathrm{A}_{0}, \quad \mathrm{~A}_{1}-\text { value of the } \\
\text { company's assets at the } \\
\text { beginning and end of the } \\
\text { year, rub. }\end{array}$ \\
\hline
\end{tabular}




\begin{tabular}{|c|c|c|}
\hline $\begin{array}{l}6 \text { Share of } \\
\text { innovative products } \\
\text { in the total volume } \\
\text { of manufactured } \\
\text { products }\end{array}$ & $\mathrm{S}_{\mathrm{IP}}=\frac{\mathrm{V}_{\mathrm{IP}}}{\mathrm{V}_{\mathrm{TP}}} * 100 \%$ & $\begin{array}{l}\mathrm{V}_{\mathrm{IP}}-\text { volume of innovative } \\
\text { products mastered in } \\
\text { production; } \mathrm{V}_{\mathrm{TP}}-\text { total } \\
\text { volume of manufactured } \\
\text { products }\end{array}$ \\
\hline $\begin{array}{l}7 \text { Share of } \\
\text { expenses for } \\
\text { science, research } \\
\text { and development in } \\
\text { the total expenses } \\
\text { of the company }\end{array}$ & $\mathrm{S}_{\mathrm{RE}}=\frac{\mathrm{V}_{\mathrm{RE}}}{\mathrm{V}_{\mathrm{TE}}} * 100 \%$ & $\begin{array}{l}\mathrm{V}_{\mathrm{RE}}-\text { expenses for science, } \\
\text { research and development; } \\
\mathrm{V}_{\mathrm{TE}}-\text { total expenses of the } \\
\text { company }\end{array}$ \\
\hline $\begin{array}{l}8 \text { Renovation of } \\
\text { fixed assets }\end{array}$ & $\mathrm{F}_{\mathrm{A}}=\frac{\mathrm{F}_{1}}{\mathrm{~F}_{2}} * 100 \%$ & $\begin{array}{l}F_{1}-\text { the cost of newly } \\
\text { introduced fixed assets for a } \\
\text { certain period; } F_{2}-\text { the cost } \\
\text { of fixed assets at the end of } \\
\text { the same period. }\end{array}$ \\
\hline $\begin{array}{l}9 \text { Level of staff } \\
\text { motivation to carry } \\
\text { out innovative } \\
\text { activities }\end{array}$ & $\mathrm{M}=\frac{I_{2}}{L} * 100 \%$ & $\begin{array}{l}I_{2}-\text { final indicator of staff } \\
\text { motivation (the result of the } \\
\text { survey); } L-\text { total number of } \\
\text { employees. }\end{array}$ \\
\hline $\begin{array}{l}10 \text { Changes in the } \\
\text { educational level } \\
\text { and professional } \\
\text { qualifications of } \\
\text { company } \\
\text { employees }\end{array}$ & $\begin{array}{l}\mathrm{P}_{\mathrm{ED}} \\
=\frac{0.42 * \mathrm{~N}_{\mathrm{H}}+0.36 * \mathrm{~N}_{\mathrm{EX}}+0.22 * \mathrm{~N}_{\mathrm{T}}}{\mathrm{N}_{\mathrm{TOT}}} \\
* 100 \% \\
\qquad \mathrm{P}_{\mathrm{ED}}=\mathrm{P}_{\mathrm{ED} 1}-\mathrm{P}_{\mathrm{ED} 0}\end{array}$ & $\begin{array}{l}\mathrm{N}_{\mathrm{H}}-\text { number of personnel } \\
\text { with higher education; } \mathrm{N}_{\mathrm{EX}}- \\
\text { number of personnel with at } \\
\text { least } 5 \text { years of work } \\
\text { experience; } \mathrm{N}_{\mathrm{T}}-\text { number of } \\
\text { personnel who underwent } \\
\text { advanced training for the } \\
\text { year; } \mathrm{N}_{\text {tot }}-\text { total number of } \\
\text { employees in the department; } \\
\text { Ped }{ }_{0} \text {, Ped }- \text { educational } \\
\text { level and professional } \\
\text { qualifications of the } \\
\text { company's employees at the } \\
\text { beginning and end of the } \\
\text { year, rubles; } 0.42 ; 0.36 \text {; } 0.22 \\
- \text { degree of influence of } \\
\text { education } \mathrm{N}_{\mathrm{H}} \text {, work } \\
\text { experience } \mathrm{N}_{\mathrm{EX}} \text { and } \\
\text { advanced training } \mathrm{N}_{\mathrm{T}} \text { on } \\
\text { labor productivity. }\end{array}$ \\
\hline
\end{tabular}

\section{Results}

The calculation of the main indicators of the company's innovative growth was carried out based on the results of the activities of a large diversified energy company operating in the Tyumen and Kurgan regions - SUENCO JSC. The territory of the company's presence includes such cities and regions of Russia as: Tyumen, Tobolsk, Ishim, Zavodoukovsk, Yalutorovsk, Uvat, as well as 24 districts of the Trans-Urals, including the cities of Kurgan and Shadrinsk.

In the electric power industry, the length of SUENCO's networks is approaching 40 thousand km, 12 thousand power grid facilities (substations, transformer substations and distribution points) are owned by it.

In the field of heat and water supply and sewerage, the company serves a total of 1,000 $\mathrm{km}$ of networks, 17 water intakes, 146 boiler houses, 7 water treatment plants, 3 sewage treatment plants. 
SUENCO is the largest investor in the power industry in the south of the Tyumen region and the entire Trans-Urals.

The main types of services provided by the company include: transportation of electrical energy, technological connection, maintenance, transmission and transportation of heat energy, water supply and disposal. $[13,14]$

The company has been the largest investor in the power industry of the Tyumen region and Trans-Urals for many years.

According to the company's financial statements, the indicators of innovative growth were calculated, taking into account single and group weight coefficients (Table 2).

Table 2. Calculation of the integral indicator.

\begin{tabular}{|c|c|c|c|}
\hline Indicator name & $\begin{array}{l}\text { Calculation } \\
\text { result }\end{array}$ & $\begin{array}{l}\text { Unit weight } \\
\text { coefficient }\end{array}$ & $\begin{array}{l}\text { Group weight } \\
\text { coefficient }\end{array}$ \\
\hline 1 Increase in intangible assets, $\%$ & 13.4 & 0.3 & \multirow[t]{4}{*}{0.3} \\
\hline 2 Increase in net (retained) profit, $\%$ & 29.67 & 0.3 & \\
\hline 3 Increase in sales revenue, $\%$ & 65.89 & 0.3 & \\
\hline $\begin{array}{l}4 \text { Increase in fixed and current assets of the } \\
\text { company, } \%\end{array}$ & 16.08 & 0.1 & \\
\hline \multicolumn{2}{|l|}{ Calculation of the integral indicator for group 1} & 30.3 & 0.09 \\
\hline $\begin{array}{l}5 \text { Share of innovative products in the total } \\
\text { volume of manufactured products, } \%\end{array}$ & 5.21 & 0.4 & \multirow[t]{2}{*}{0.3} \\
\hline $\begin{array}{l}6 \text { Share of expenses for science, research and } \\
\text { development in the total expenses of the } \\
\text { company, \% }\end{array}$ & 0.02 & 0.6 & \\
\hline \multicolumn{2}{|l|}{ Calculation of the integral indicator for group 2} & 2.11 & 0.006 \\
\hline 7 Renovation of fixed assets, $\%$ & 93.18 & 0.6 & \multirow[t]{2}{*}{0.2} \\
\hline $\begin{array}{l}8 \text { Flexibility indicator, the ability of a company } \\
\text { to reallocate resources from one type of activity } \\
\text { to another to release new products and services, } \\
\%\end{array}$ & 0.04 & 0.4 & \\
\hline \multicolumn{2}{|l|}{ Calculation of the integral indicator for group 3} & 55.92 & 0.112 \\
\hline $\begin{array}{l}9 \text { Level of staff motivation to carry out } \\
\text { innovative activities, } \%\end{array}$ & 12.72 & 0.5 & \multirow[t]{2}{*}{0.2} \\
\hline $\begin{array}{l}10 \text { Changes in the educational level and } \\
\text { professional qualifications of company } \\
\text { employees, \% }\end{array}$ & 37.41 & 0.5 & \\
\hline \multicolumn{2}{|l|}{ Calculation of the integral indicator for group 4} & 25.1 & 0.05 \\
\hline General integral indicator of innovative growth & & \multicolumn{2}{|c|}{0.26} \\
\hline
\end{tabular}

Based on the value of the general integral indicator, it is possible to reveal the level of innovative growth of an energy company using the data in Table 3.

Table 3. The level of innovative growth of the company.

\begin{tabular}{|l|c|l|}
\hline $\begin{array}{c}\text { Characteristics of } \\
\text { innovative growth }\end{array}$ & $\begin{array}{c}\text { Interval of values of } \\
\text { innovative growth }\end{array}$ & \multicolumn{2}{|c|}{$\begin{array}{l}\text { Recommended areas of the company's } \\
\text { innovative growth strategy }\end{array}$} \\
\hline $\begin{array}{l}\text { High innovative } \\
\text { growth }\end{array}$ & $I G>2$ & $\begin{array}{l}\text { Extensive innovative growth strategy } \\
\text { (innovation and technological growth) }\end{array}$ \\
\hline $\begin{array}{l}\text { Average rate of } \\
\text { innovative growth }\end{array}$ & $I<I G \leq 2$ & $\begin{array}{l}\text { Intensive innovative growth strategy } \\
\text { (modernization) }\end{array}$ \\
\hline $\begin{array}{l}\text { Low rate of } \\
\text { innovative growth }\end{array}$ & $0<I G \leq 1$ & $\begin{array}{l}\text { Diversified innovative growth strategy } \\
\text { (market innovations) }\end{array}$ \\
\hline No innovative growth & $I G \leq 0$ & $\begin{array}{l}\text { Radical innovative growth strategy } \\
\text { (organizational and managerial innovations) }\end{array}$ \\
\hline
\end{tabular}




\section{Discussions}

The result of a comprehensive assessment and the calculation of the integral indicator serve as final indicators that focus on the main problems of innovative growth and help to correct the identified inconsistencies in time. The value of the revealed integral indicator equal to 0.26 corresponds to the strategy of diversified innovative growth (development of new sales markets and technologies), which suggests that at the analyzed enterprise, new sales and distribution networks, supply chains are being built, a marketing policy is being developed, changes in the structure are taking place, including the formation of vertically integrated branches and representative offices, the packaging and design of products are changing, the range of products is updating and expanding.

\section{Recommendations}

The materials of the paper can be important among the leaders of companies in the energy and other industries in assessing the current level of innovative growth of the company. At the same time, it is important to understand that the set of indicators for assessing innovative growth can be changed with reference to a specific type of company activity, but it must remain unchanged for assessment in dynamics.

\section{References}

1. S. Valdaitsev, Management of research, development and innovation projects (1995)

2. P. Zavlin, Assessment of the effectiveness of innovation (1998)

3. N. Kondratyev, Big cycles of conjuncture and the theory of foresight (2002)

4. A.G. Porshnev, Organization management (2017)

5. R.A. Fatkhutdinov, Innovation management (2011)

6. N. Vatin, A., Gorshkov, et al., Applied Mechanics and Materials. 2014. 670-671. Pp. 365-369. DOI:10.4028/www.scientific.net/AMM.670-671.365

7. A. Lukyanov, Innovation: search and birth of something new (2008)

8. V.G. Medynsky, Innovation management (2007)

9. B. Twiss, Managing technology for competitive advantage (1989)

10. A.A. Trifilova, Management of innovative development of an enterprise (2003)

11. A. Minnullina, E3S Web of Conferences 33, 03060 (2018) doi:10.1051/e3sconf/20183303060

12. A. Minnullina, E3S Web Conf. 164, 09023 https://doi.org/10.1051/e3sconf/202016409023

13. Key performance indicators of SUENCO JSC, https://www.suenco.ru/upload/iblock/e9e/Predlozhenie-o-razmere-tsen-_tarifov_dolgosrochnykh-parametrov-regulirovaniya-na-2020-god-po-Kurganskoy-oblasti.pdf

14. Vatin, N., Gorshkov, A., Nemova, D., Tarasova, D. Applied Mechanics and Materials. 2014. 633-634. Pp. 991-996. DOI:10.4028/www.scientific.net/AMM.633-634.991.

15. G. Kozlov, et al. E3S Web of Conferences 175, 12015 (2020) do:10.1051/e3sconf/202017512015 